\title{
INTEGRASI AGAMA DAN BUDAYA: KAJIAN TENTANG TRADISI MAULOD DALAM MASYARAKAT ACEH
}

\author{
Abidin Nurdin \\ Universitas Malikussaleh, Aceh \\ Email: abidin_majene@yahoo.co.id
}

\section{Abstract}

Islam and tradition in Aceh community are like substance and attribute that are inseparable. Religion and culture have been integrated in way of life, social system, culture and Islamic values. In cultural perspective, maulod tradition has been a ritual which integrates between traditional and religious values that are intertwined. This study used sociological and religion anthropology approach by using data collection such as observation, interview and library research. The result of this study describes that the maulud tradition in Aceh integrated between religion and culture. Islam influences culture deeply as shown in almost the whole social life aspects of Aceh community. It can be found in process of uroe maulod, idang meulapeh, dzikee maulod and Islamic da'wah. Indeed, maulod celebration is held not only in a month but also in three months namely; Rabiul Awal (the first maulod), Rabiul Akhir (the middle maulod) and Jumadil Awal (the last maulod).

Islam dan adat dalam masyarakat Aceh bagaikan zat dan sifat yang tidak dapat dipisahkan satu sama lain. Agama dan budaya terintegrasi dalam pandangan hidup, sistem sosial, budaya, dan nilai-nilai Islam. Dari konteks budaya, tradisi maulod menjadi praktik keagamaan yang kental dengan integrasi nilai-nilai agama dan adat yang saling berkelit kelindang. Kajian ini menggunakan pendekatan sosiologi dan antropologi agama dengan teknik pengumpulan data melalui observasi, wawancara dan studi kepustakaan. Hasil penelitian ini menunjukkan bahwa dalam tradisi maulod di Aceh terjadi integrasi antara agama dan budaya. Islam mewarnai budaya secara begitu kental, sebagaimana juga ditemukan dalam hampir seluruh aspek kehidupan bagi masyarakat Aceh. 
Hal ini dapat dilihat dalam proses uroe maulod, idang meulapeh, dzikee maulod, dakwah Islamiah. Bahkan perayaan maulod tidak hanya sebatas satu bulan saja, namun dilaksanakan dalam tiga bulan yaitu, Rabiul Awal (maulod awai), Rabiul Akhir (maulod teungoh) dan pada bulan Jumadil Awal (maulod akhe).

Keywords: Maulod tradition; Aceh community

\section{Pendahuluan}

Islam hadir di Nusantara bukan dalam masyarakat hampa budaya. Praktik budaya justru diakomodir dan diadopsi kemudian diislamisasi. Islam tidak menggusur budaya yang hidup dalam masyarakat di mana Islam datang untuk mencerahkan akidah umat. Islam meluruskan, memberi nilai, makna dan penguatan terhadap budaya yang sudah hidup lama dalam satu masyarakat yang didakwahinya.

Hadi (2006: 19) menyebutkan tiga pola penyebaran Islam di kepulauan Nusantara, yaitu; integratif, dialogis, dan gabungan dialogis-integratif.

Pertama, integratif, sebagian besar aspek kehidupan dan kebudayaan suatu komunitas diintegrasikan dengan pandangan hidup, gambaran dunia, sistem pengetahuan dan nilai-nilai Islam. Contohnya masyarakat etnik-etnik Melayu di Aceh, Sumatera, Kalimantan, Palembang, Riau, Banjar, pesisir Jawa seperti Banten, Jawa Timur dan Madura. Pola ini dapat dilakukan karena sebelum raja atau penguasa memeluk Islam, masyarakat ramai sudah memeluk agama Islam dan mengembangkan kebudayaan bercorak Islam.

Kedua, dialogis; Islam dipaksa berdialog dengan tradisi lokal yang sudah tertanam dalam masyarakat. Contohnya yaitu di Jawa pedalaman, yang langsung berada di bawah pengaruh kraton. Mistisisme Islam berkembang di wilayah ini berpadu dengan tradisi mistik lama warisan zaman Hindu. Seni dan sastra zaman Hindu dipertahankan dengan memberi corak Islam. Pola ini dilakukan karena sistem kekuasaan masih mempertahankan sistem lama, dan masyarakat masih belum sepenuhnya terislamkan.

Ketiga, pola gabungan antara dialogis dan integratif terjadi di Indonesia bagian Timur misalnya di Sulawesi. Ini karena yang pada mulanya memeluk Islam adalah raja dan para bangsawan, baru diikuti oleh rakyat yang budayanya beragam.

Ketiga pola tersebut dapat disaksikan dalam tradisi dan ritual keagamaan yang masih dipraktikkan oleh masyarakat Nusantara sampai saat ini. Mulai dari upacara aqiqah, tahlilan, Idul Fitri, Idul Adha, isra' mikraj dan maulid. 
Tradisi tersebut ditemukan berbeda antara satu daerah dengan lainnya. Maulid di Yogyakarta misalnya, diperingati dengan tradisi Grebek Mulud prosesi arakarakan gunungan dari Keraton Ngayogyakarta Hadiningrat menuju alun-alun utara dan berakhir di masjid Agung Kauman. Ada juga yang mengaitkannya dengan Sekaten yang berasal dari kata syahadatain yaitu dua kalimat syahadat (Jati, 2012 dan Purwadi, 2014). Di Kalimantan Selatan terdapat tradisi Baayun Mulud. Perayaan maulid diramaikan dengan anak yang diayun. Maudu Lompoa di sekitar Cikoang Takalar, Sulawesi Selatan, sarat dengan nilai tasawuf, ratusan perahu dihiasi dengan telor dan aneka makanan. Kemudian Babaca Maulid Nabi dipadu dengan alunan rebana di Ternate. Sementara di Sumatera Barat dikenal dengan Malamang dan Mulud Badikia makanan lemang dan berdzikir (Sila, 2001; Maimanah \& Norhidayat, 2012; Pramono, 2010).

\section{Agama dan Akulturasi Budaya}

Agama termasuk Islam, mengandung simbol-simbol sistem sosial-kultural yang memberikan suatu konsepsi tentang realitas dan rancangan untuk mewujudkannya. Tetapi simbol-simbol yang menyangkut realitas ini tidak selalu harus sama dengan realitas yang terwujud secara riil dalam kehidupan masyarakat. Ajaran agama manapun, konsepsi manusia tentang realitas tidaklah bersumber dari pengetahuan, tetapi kepercayaan pada otoritas mutlak yang berbeda dari suatu agama dengan agama lainnya. Di dalam Islam, konsepsi realitas berasal dari wahyu al-Qur'an dan Hadis. Konsepsi dasar realitas yang diberikan kedua sumber ini dipandang bersifat absolut dan karenanya, transenden dari realitas sosial (Azra, 1999: 11).

Namun agama juga merupakan realitas sosial, ia hidup dan termanifestasi di dalam masyarakat. Di sini doktrin agama yang merupakan konsepsi tentang realitas harus berhadapan dengan kenyataan adanya, dan bahkan keharusan atau sunnatullah dalam bentuk perubahan sosial. Dengan demikian al-Qur'an yang diyakini kaum Muslimin sebagai kebenaran final yang tidak dapat diubah dan berlaku untuk segala waktu dan tempat berbenturan dengan kenyataan sosial yang selalu berubah.

Pertanyaan yang muncul kemudian, jika Islam (atau lebih sempit dan tegas al-Qur'an) yang tidak boleh diubah itu merupakan konsepsi tentang realitas, apakah Islam merupakan pendukung atau sebaliknya hambatan terhadap perkembangan budaya? Dalam bentuk yang lebih populer, apakah Islam menjadi penghalang bagi perubahan sosial yang menuju ke arah kesejahteraan kemanusiaan?

el Harakah Jurnal Budaya Islam Vol.18 No.1 Tahun 2016 
Sepanjang sejarah sejak masa-masa awal telah tercipta semacam ketegangan antara doktrin teologis Islam dengan realitas dan perkembangan sosial. Tetapi, dalam aplikasi praktis, Islam "terpaksa" mengakomodasi kenyataan sosial-budaya. Tatkala doktrin-doktrin pokok al-Qur'an tentang fikih, misalnya dirumuskan secara rinci, ketika itu pulalah para ahli fikih - terpaksa mempertimbangkan faktor-faktor sosial budaya. Karena itulah antara lain tercipta perbedaanperbedaan - betapapun kecilnya, misalnya diantara imam-imam madzhab. Imam as-Syafi'i misalnya, mengembangkan apa yang disebut qaul qadim ketika dia di Irak dan qaul jadid ketika pindah ke Mesir (Azra, 1999: 12).

Jadi sejak awal perkembangannya Islam sebagai konsepsi realitas telah menerima akomodasi sosio-kultural. Akomodasi ini semakin terlihat ketika wilayah Islam berkembang sedemikian rupa sehingga ia menjadi agama yang mendunia. Pada kasus-kasus tertentu, akomodasi itu tercipta sedemikian rupa, sehingga memunculkan berbagai "varian Islam". Terlepas dari setuju atau tidak inilah yang menyebabkan Geertz (dalam Azra, 1999), misalnya, lebih senang menyebut Islam di Jawa sebagai "religion of java" atau sementara orang Arab menyebut Syi'ah di Iran sebagai suatu "agama Persia” ketimbang Islam itu sendiri.

Konsep integrasi atau akomodasi tersebut semakin tampak jika dikaitkan dengan pandangan yang mengatakan, bahwa Islam tidak seharusnya dilihat pada konteks agama wahyu dan doktrinal saja. Tetapi Islam harus dilihat juga sebagai fenomena dan gejala budaya dan sosial (Mudzhar, 1998: 13-14). Pada konteks inilah Islam berkelit kelindan dengan budaya dan sejarah, sehingga memunculkan mozaik Islam baru dan bercorak dan berwatak lokal dalam hal ini Islam dalam warna budaya dimana agama tersebut tumbuh dan berkembang, Timur Tengah, Afrika, Eropa, Asia termasuk di Indonesia dan Aceh.

Jika mengikuti alur pikir akomodasi tersebut, maka akan memunculkan setidaknya dua varian Islam yang disebut dengan menggunakan berbagai istilah. Islam sebagai konsepsi budaya disebut great tradition (tradisi besar), sedangkan Islam sebagai realitas budaya disebut little tradition (tradisi kecil) atau local tradition (Koentjaraningrat, 1980: 170). Great tradition pada hakikatnya mewakili Islam sebagai konsepsi realitas dan little tradition (tradisi kecil) atau local tradition (tradisi lokal). Atau dengan kata lain, "Islam" dan "Islamicate" bidang-bidang yang "Islamik", yang dipengaruhi Islam (Azra, 1999: 13)

Tradisi besar (Islam) tentu saja adalah Islam yang dipandang sebagai doktrin yang normatif dan original, yang permanen, atau setidak-tidaknya merupakan interpretasi yang melekat ketat pada ajaran dasar. Dalam lingkup 
lebih sempit, doktrin ini tercakup di dalam konsepsi-konsepsi keimanan dan syariah yang mengatur pola berpikir dan bertindak setiap muslim. Tradisi besar ini sering pula disebut tradisi pusat yang dikontraskan dengan pinggiran. Pada pihak lain, tradisi kecil (tradisi lokal, Islamicate) adalah realm of influence - kawasan-kawasan yang berada di bawah pengaruh Islam atau tradisi besar tersebut.

\section{Integrasi Hukom Ngon Adat}

Falsafah hidup orang Aceh adalah integrasi antara hukom ngon adat (agama dan adat) terdapat dalam hadih majah (pepatah) "Hukom ngon Adat lagee zat ngon sipheut" (hukum [agama] dan adat bagai zat dan sifat, tak dapat dipisahkan) (Hoesein, 1970: 1). Hadih maja yang lain; "hukom meunyo hana adat tabeue, adat meunyo hana hukom bateue" (Hukum jika tanpa adat hambar, adat jika tanpa hukum batal) (Muhammad \& Sumardi, 2011: 37). Hal ini dapat dipahami bahwa antara budaya dan ajaran Islam telah berinteraksi dan berasimilasi secara harmonis dalam masyakarat Aceh sepanjang ratusan tahun. Bentuk konkrit adat dan budaya dalam kehidupan masyarakat Aceh tidak hanya teraplikasi dalam bidang sosial, ekonomi maupun politik, tetapi juga dalam bidang hukum (Nurdin, 2013: 139).

Karena itu, Islam menjadi way of life yang mengkristal dalam budaya dan adat Aceh tampaknya tidak dapat dibantah. Dalam sistem, pranata dan struktur sosial cukup menonjol, artinya Islam dijadikan sebagai world view (pandangan hidup). Misalnya, sistem pemerintah yang paling tinggi nanggroe (kerajaan atau negara) sampai pada level yang paling rendah (gampong). Pada tingkat kerajaan dahulu sultan mengurusi masalah, sosial, politik dan tata negara, sedangkan agama dan adat berada dalam kewenangan qadhi (ulama) sebagai penasihat sultan pada saat itu. Qadhi yang terkenal adalah Syamsuddin as-Sumatrani (w. 1630 M), Nuruddin ar-Raniri (w. 1658) dan Abdurrauf asSingkili (w. 1693). Para ulama inilah yang mewarnai proses sosial, politik dan budaya dalam masyarakat Aceh. Kemudian pada level gampong yang dipimpin oleh keuchik (kepala desa) yang mengurusi persoalan pemerintahan. Di samping itu, ada imum meunasah yang memimpin semua urusan keagamaan. Sampai saat ini biasa kantor keuchik dan meunasah selalu berdekatan atau dalam satu kompleks, bahkan dahulu meunasah juga dijadikan sebagai kantor keuchik (Nurdin, 2015).

Pemahaman dan praktik ajaran Islam dalam masyarakat Aceh sebagaimana disebutkan sangat kental dengan konsep integrasi dan akomodasi. Menurut 
Badruzzaman Ismail, Ketua Majelis Adat Provinsi Aceh bahwa adat Aceh sangat kental dengan warna Islam. Nilai-nilai Islam seperti humainisme, persamaan, perdamaian, kebersamaan teraplikasi dalam adat, budaya masyarakat Aceh. Misalnya, konflik yang terjadi dalam didamaikan dengan pendekatan adat yang dikenal dengan suloh. Suloh berasal dari Islam yaitu islah, artinya damai (wawancara 22 Juli 2015).

Sejalan dengan itu, pada lembaga adat Panglima Laot (institusi adat yang mengurusi masalah laut) ada larangan melaut dan menangkap ikan pada hari Jumat. Hal ini didasari bahwa pada hari itu nelayan difokuskan untuk salat Jumat. Demikian pula lembaga adat Mukim, yang merupakan instutisi adat yang berada di atas gampong. Berasal dari kata mukim (Bahasa Arab artinya yang menetap). Masjid hanya dapat dibangun dan digunakan untuk salat Jumat di wilayah pemukiman, karena dalam pandangan madzhab Imam as-Syafi'i syarat sah salat Jumat jika dihadiri empat puluh orang yang mukim. Madzhab ini merupakan mayoritas dianut dalam masyarakat Aceh sampai saat ini.

Hadih maja, praktik agama dan budaya tersebut di atas mencerminkan pandangan masyarakat Aceh tentang hubungan antara agama yang disebut hukom dan budaya yang dikenal sebagai adat. Jika mengacu pada konsep dua tradisi tersebut di atas, maka hukom atau agama dapat disebut sebagai tradisi besar karena ia adalah doktrin yang berasal dari al-Qur'an dan as-Sunnah, sedangkan adat dan budaya merupakan tradisi kecil yang harus mendapat dukungan dari doktrin tersebut.

Konsep akomodasi antara kedua tradisi tersebut begitu kental dalam masyarakat Aceh, oleh karena itu tidak mengherankan jika sampai saat ini tidak sedikit tradisi yang kental dengan warna lokal Aceh. Tradisi tersebut menjadi syiar dan daya tarik tersendiri bagi masyarakat Aceh dan bagi orang luar. Seperti tradisi, Maulid, Israk Mikraj, Idul Fitri, Idul Adha, dan 1 Muharram.

Maulid Nabi sesuai dengan konteksnya telah dianggap sebagai salah satu aspek dari kebudayaan dan syiar Islam yang perlu dilestarikan. Hal ini disebabkan oleh aliran pemikiran agama yang juga karena faktor budaya lokal masyarakat Islam yang berdomisili di suatu tempat. Perbedaan waktu, bentuk perayaan Maulid Nabi bukanlah persoalan substantif, karena maulid Nabi diikat oleh akidah Islam sebagai keyakinan bagi umat Islam untuk memuliakan Rasul Muhammad saw. 


\section{Uroe Maulod}

Maulod dapat dikatakan hari raya ketiga setelah Idul Fitri dan Idul Adha. Masyarakat juga biasanya akan uwo gampong (pulang kampung) dalam tiga waktu tersebut. Perayaan maulod merupakan bentuk penghormatan dan kecintaan kepada Nabi Muhammad saw. Hal ini yang disebut Schimmel (1991: 52) sebagai penghormatan kepada Nabi dan perhatian kepada rincian yang paling kecil pun dari perilaku serta kehidupan pribadinya tumbuh sejalan dengan semakin jauhnya jarak waktu kehidupan kaum muslim dengan Nabi. Mereka ingin mengetahui lebih banyak lagi mengenai kepribadiannya, pandangan-pandangannya, dan perkataan-perkataannya, untuk meyakinkan mereka bahwa mereka telah mengikutinya dengan cara yang benar.

Dahulu dalam masyarakat Aceh pada malam 12 Rabiul Awal, disambut dengan membakar lilin atau lampu-lampu kecil di pasang di depan rumah dan diadakan kenduri (slametan) sambil membaca kisah-kisah Nabi Muhammad yang terdapat dalam kitab al-Barzanji. Kemudian peringatan maulod diadakan selama lebih 100 hari sesudahnya atau dikenal dengan "lhee buleuen siploh uroe" (tiga bulan sepuluh hari). Kenduri yang diadakan setelah malam 12 Rabiul Awal biasanya diadakan pada siang hari (Hoesein, 1970: 123). Namun saat ini membakar lilin dan kenduri pada malam 12 Rabiul Awal sudah banyak tidak dilakukan, kecuali setelahnya.

Perayaan maulod yang dilaksanakan dalam tiga bulan tersebut yaitu, bulan Rabiul Awal (maulod awai), Rabiul Akhir (maulod teungoh) dan pada bulan Jumadil Awal (maulod akhe). Menurut Teungku Husnaini Hasbi salah seorang Imam Kemukiman di Lhokseumawe menegaskan bahwa di samping karena bulan-bulan tersebut dianggap berberkah juga dilatarbelakangi oleh keadaan dan kondisi masyarakat dahulu yang lebih banyak petani. Keadaan ekonomi membaik seiring tibanya masa panen, ketiga bulan tersebut di atas biasa adalah bulan panen padi. Pada saat itulah masyarakat mempunyai kemampuan untuk melaksanakan maulid karena ketersediaan beras yang melimpah dan uang untuk menyiapkan hal-hal lainnya (wawancara September 2015).

Orang Aceh merayakan maulod secara meriah pada waktu yang tidak bersamaan di masing-masing gampong. Lamanya waktu pelaksanaan maulid ini di satu sisi diyakini sebagai upaya untuk memberikan kepada berbagai lapisan masyarakat agar dapat memilih kapan waktunya yang tepat untuk melaksanakan kenduri tersebut. Di sisi yang lain juga dapat dibaca sebagai sebuah kemaslahatan yang akan dipilih oleh masyarakat untuk mempersiapkan diri secara baik dalam rangka menyambut peringatan maulod tersebut. 
Pada hari "Uroe Maulod", masyarakat dengan ikhlas menyedekahkan makanan siap saji untuk dinikmati bersama yang dipusatkan di meunasah atau masjid setempat. Makanan yang disedekahkan masyarakat berupa nasi yang dibungkus dengan daun pisang berbentuk segi tiga yang dinamakan dengan "bue kulah" beserta lauk pauk mulai dari gulai ayam kampung, gulai kambing, gulai ikan, telur bebek, sayur nangka, buah-buahan, kue dan lainlain. Makanan-makanan tersebut dibungkus dengan tudung saji dan di atasnya biasa dilapisi dengan kain yang berwarna keemasan. Tudung saji tersebut berbentuk kerucut dengan warna dominan hijau, kuning, dan hitam yang dinamakan "Idang Meulapeh".

Pada saat "Uroe Maulod", representasi anak-anak yatim dan fakir miskin mendapat pelayanan khusus dari masyarakat sebagai wujud kecintaan mereka kepada golongan tersebut. Bahkan ada di beberapa daerah di Aceh, masyarakat disamping menyediakan kenduri secara maksimal, juga menyantuni mereka dengan sejumlah uang dan berbagai bingkisan lainnya untuk dibawa pulang. Tradisi ini hampir merata dilakukan di seluruh Aceh, karena momen tersebut sekaligus dapat bermakna ganda. Di satu sisi, terlaksananya acara kenduri maulid, namun di sisi yang lain dapat juga tersantuni anak-anak yatim dan fakir miskin yang juga merupakan refleksi dari anjuran Rasul yang terdapat dalam al-Qur'an dan as-Sunnah.

Bagi masyarakat Aceh, tradisi ini dilakukan sebagai momentum untuk meningkatkan pemahaman masyarakat terhadap Islam, memperkuat keimanan kepada Allah swt. dan kecintaan mereka kepada Rasulullah saw., serta memperkokoh ukhuwah Islamiah untuk menumbuhkan solidaritas sosial, memperkuat ikatan sosial dan kepekaan terhadap nasib sesama. Itulah tujuan dasar dari tradisi tersebut, dan tujuan ini relevan dengan tujuan Islam.

Jika perayaan maulod diadakan di satu meunasah maka meunasah yang lain diundang untuk menyantap hidangan, demikian pula jika dilaksanakan satu gampong maka gampong lain juga diundang, sama halnya dengan pemukiman. Undangan biasanya sekitar 50-100 orang untuk masing-masing gampong, mereka menyantap hidangan di dalam atau di pelataran meunasah atau masjid. Undangan duduk bersila dan melingkar, menghadap idang yang lengkap lauk pauk dan bu kula. Prosesi ini dilaksanakan pada siang hari sesudah salat Dhuhur, atau sesudah Ashar. Setelah mereka menyantap hidangan, setiap kepala keluarga akan diberikan bungkusan yang berisi lauk pauk dan bue kula. Khusus untuk di Aceh Besar dan Banda Aceh biasanya akan diberikan kuah belangon (gulai sapi atau lembu) yang dimasak secara bersama di meunasah atau masjid. 
Dahulu masyarakat Aceh melaksanakan maulod dalam tiga tingkatan, yaitu (Soelaiman, 2011: 166): (1) Di tingkat meunasah atau gampong dilakasanakan pada maulod awai (awal) yaitu bulan Rabiul Awal; (2) Di tingkat kemukimam dilaksanakan pada maulod teungoh (tengah) di bulan Rabiul Akhir; (39 Di rumah ulee balang (keturunan raja) yang disebut maulod akhe (akhir), atau maulod tulot pada bulan Jumadil Awal. Pada kesempatan itu raja atau ulee balang makan khanduri bersama dengan masyarakat.

Seiring dengan perkembangan zaman, ada perubahan yang terjadi. Perayaan maulod tidak lagi berdasarkan tingkatan, sebab yang penting adalah bahwa masa merayakan maulod itu sampai tiga bulan. Jadi selama masa itu di setiap Gampong atau pemukiman, dapat diadakan perayaan maulod tergantung kepada keinginan dan kesiapan sebuah gampong untuk mengadakannya. Namun biasanya antara gampong yang satu dengan yang lain, tidak terlalu berselang karena masih dalam satu pemukiman.

Di daerah Pidie dan Banda Aceh pada hari maulod anak yatim dan fakir miskin akan di undang ke rumah untuk menyantap hidangan sebelum perayaan diadakan di meunasah atau masjid. Sebagai cerminan bahwa Nabi Muhammad saw. sangat mencintai anak yatim dan fakir miskin. Mereka juga secara khusus dihadirkan di meunasah terkadang diberikan pakaian dan uang.

Sedangkan di Nagan Raya, maulod dirayakan agak berbeda dengan daerah lain karena berlangsung sekurang-kurangnya dua hari (meskipun tetap berlangsung selama tiga bulan); satu hari diistilahkan dengan uro meuroh (hari untuk mengundang) dan hari selanjutnya diistilahkan dengan uro dzikee (hari dzikir atau hari kenduri). Pada uro meuroh, pemilik rumah mendatangi sejumlah rumah handai taulan dan kerabat dan mengundang mereka untuk menghadiri jamuan kenduri di rumahnya pada esok hari. Orang-orang yang diundang tersebut akan berusaha maksimal untuk memenuhi undangan itu karena pengundang akan merasa sangat bahagia jika undangannya dipenuhi. Seandainya orang yang diundang itu sengaja ke luar gampong atau berpergian pada hari kenduri, akan dianggap sebagai memutuskan silaturrahmi kecuali ada hal-hal yang sangat mendesak. Selain itu, di Nagan Raya ada kenduri untuk Habib (Habib Abdur Rahim bin Habib Abdul Qadir Ramaa'n bin Sayyid Athah al-Qadiri atau Habib Muda Seunagan, penganut tarekat Syattariyah (pendapat lain Qadariyah wa Naqsyabandiyah) yang juga diistilahkan dengan Maulod Habib. Tradisi kenduri ini masih dipraktikkan sampai saat ini. Maulod Habib dilaksanakan pada malam hari dan siang harinya menikmati hidangan Maulid Nabi (Melayu, 2012: 143). Menariknya Maulod Habib bagi pengikut 
Habib Muda Seunagan pada malam hari dilakukan dzikee sepanjang malam yang diikuti oleh masyarakat termasuk perempuan dan anak yang berkumpul pada di makam Habib sambil berdzikir.

Pada saat perayaan maulod dalam masyarakat Aceh terdapat tiga tahapan kegiatan. Pertama, pada pagi hari kenduri khusus untuk anak yatim dan fakir miskin, mereka makan dan diberikan amplop atau kain sarung. Kedua, pada siang hari para tamu dari gampong tetangga atau dari para pejabat setempat dan tim dzikir (beberapa orang yang dipanggil berdzikir biasanya membaca shalawat dan doa kepada Nabi yang dilakukan sesudah dhuhur sampai memasuki Ashar) dijamu dengan makanan maulod. Ketiga, sesudah itu masyarakat gampong makan bersama dan selesailah acara pada siang itu.

Pada saat udangan maulod diadakan di rumah masing-masing, keluarga, handai taulan, kerabat, datang sambil membawa bungon jaroe (buah tangan) berupa gula pasir 2-4 kilo gram. Hal ini dipraktikkan di seluruh daerah di Aceh. Gula memang dianggap barang yang cukup berharga di Aceh karena dapat diuangkan kembali. Demikian pula jika kenduri kematian dan aqiqah masyarakat juga membawa gula, meskipun juga ada yang membawa amplop yang berisi sejumlah uang, namun jika acara maulod tidak ada yang membawa uang.

\section{Dzikee Maulod}

Prosesi maulid Nabi di sebagian daerah di Aceh biasanya diawali dengan kegiatan dzikir (meudzikee), sering diadakan di lapangan terbuka, terkadang juga kegiatan dzikir tersebut dilakukan di meunasah (musala). Dalam dzikir tersebut akan dibacakan kitab Barzanji. Barzanji adalah nama sebuah kitab yang berisikan tentang sejarah kehidupan Nabi Muhammad dalam bentuk syair. Di dalamnya dideskripsikan sejarah lengkap Nabi Muhammad sejak kelahiran, pengangkatannya sebagai Rasul, perjuangan dalam mengemban risalah, sampai wafatnya.

Namun menurut catatan Kaptein (1994) perayaan maulid dimulai pada masa Dinasti Fatimiyah di Mesir, masa Mu'iz Lidinillah (953-975 M). sedangkan pembacaan "Barzanji" dimulai pada masa Salahuddin al-Ayyubi (1138-1193 M) dengan maksud untuk mengobarkan semangat melawan tentara salib, maka diadakanlah sayembara, puji-pujian dan biografi Rasulullah yang kemudian dimenangkan oleh as-Sayyid Ja'far bin Hasan bin Abdul Karim al-Barzanji (1126-1184 M) seorang mufti Syafi'i di Kota Madinah al-Munawwarah. Karya Ja'far al-Barzanji inilah yang kemudian banyak dibaca sebagai teks yang 
otoritatif tentang sejarah Nabi di seluruh belahan dunia termasuk di kepulauan Nusantara sampai saat ini setiap kali perayaan Maulid.

Jika merujuk dalam konteks wacana Islam lokal (Islamic local discourse), karya-karya ulama tersebut tentu saja menarik dan penting untuk dikaji. Sebagai bentuk penggubahan dari teks-teks sumber, karya-karya tersebut termasuk kitab Barzanji bukanlah seragam dalam penjelasan, interpretasi dan penjelasan atas doktrin-doktrin, konsep-konsep atau wacana tertentu. Para ulama telah menyesuaikan dengan lingkungan sosial dengan usaha kontekstualisasi Islam tanpa harus mengorbankan prinsip-prinsip dasar Islam, khususnya dalam bidang akidah, kalam dan bahkan fikih (Azra, 2004: 3).

Pembacaan barzanji dalam perayaan maulid di Aceh, biasanya lebih banyak dilakukan dalam Bahasa Aceh meskipun juga ada dalam bahasa Arab dilakukan oleh kelompok dzikee. Sistem pembacaan dipimpin oleh syekh atau khalifah yang diikuti oleh anggotanya atau jamaahnya. Jamaah mengikuti bacaan bait pertama dari setiap bab kitab Barzanji yang dibaca oleh khalifah. Sistem pembacaannya dimulai dengan pembacaan khalifah terhadap bait pertama dan diikuti oleh jamaah. Selanjutnya, khalifah membaca bait kedua, dan jamaah tetap mengulangi bait pertama. Demikian selanjutnya hingga khalifah menghabiskan seluruh bait dari setiap bab, sementara jamaah tetap membaca bait pertamanya saja.

Kelompok dzikiee duduk berbaris dua saling berhadapan sambil duduk bersila dengan memakai baju koko (baju muslim) atau batik seragam. Kadangkadang mereka mengangguk-anggukkan kepala, bahu dan badan seperti orang sedang menari rapai (tari tradisional Aceh). Ada juga yang dilakukan dengan cara yang memang mirip tarian. Terkadang mereka bergerak maju mundur sembari berangkulan. Dengan posisi kepala juga sesekali menunduk, mengangkat, dan seterusnya. Menariknya, jika memperhatikan ekspresi wajah pelaku dzikir tersebut, mereka seperti mengalami ekstasi (fana, dalam terminologi sufistik). Mereka takkan merasakan sakit andaipun dalam proses dzikir.

Di Aceh Tengah, Bener Meriah dan Gayo Luwes yang berasal dari etnis Gayo melaksanakan dzikee maulod dengan memainkan tari saman. Tari saman memang berasal dari daerah ini yang telah menjadi warisan dunia oleh UNESCO sejak 2011. Biasanya syair yang dipakai dalam tari saman berisi pesan-pesan dakwah, pantun nasihat, dan pantun percintaan. Pesan-pesan ini disampaikan dalam Bahasa Gayo dan Arab.

Dahulu ketika maulid akan dilakukan, dzikee dipertandingkan antar gampong, dzikee dilakukan oleh pemuda dan orang tua dengan memukul 
alat yang disebut tifa yang terbuat dari pelepah pinang, tifa dipukul sambil melantunkan dzikir dan salawat kepada Nabi. Sejak dari menjelang dhuhur sampai menjelang sore hari, istirahat pada saat salat Dhuhur. Namun sekarang dzikie hanya dilakukan oleh pemuda yang berasal dari dayah (pesantren) atau satu kelompok (grup).

Prosesi dzikee sendiri berlangsung sesudah dhuhur sampai sekitar setengah hingga satu jam menjelang magrib. Pada separuh waktu dzikee ada masa jeda untuk menikmati bu lukat dan boh peungat (nasi ketan dan kolak). Biasanya, pada waktu tersebut juga dimanfaatkan untuk salat Ashar. Pada paruh kedua prosesinya, dzikee dilakukan sambil berdiri selama sekitar setengah jam. Hal ini sebagai simbol untuk memuliakan Nabi Muhammad karena dzikee yang dibacakan ketika itu berkenaan dengan sejarah kedatangan Nabi Muhammad ke Madinah. Orang-orang Madinah menyambut kehadiran Rasul dengan posisi berdiri sehingga jamaah dzikee juga melakukan demikian. Dzikee berakhir pada sore hari dan ditutup dengan menikmati hidangan kenduri maulod. Dari beberapa sumber, didapati bahwa tradisi dzikir dengan bentuk demikian dipengaruhi oleh aliran-aliran dalam tasawuf, ada yang menyebutnya pengaruh dari aliran Naqsyabandiyah dan Syattariyah yang banyak dianut oleh masyarakat Aceh.

Berikut salah satu bait dzikee maulod dalam Bahasa Aceh;

Ya Ilahi poe ku Rabbi lon ek saksi gata Tuhan Lon ek saksi Nabi Muhammad Rasulullah gata bagi jin insan Tabri Islam dengoen Iman ngon makrifat tauhid sajan Tapeuteutap lam kalimah hudep matee bangket meunan Berkat Rasul yang troen kitab Nabi lengkap sekalian Berkat mukjizat Taha Yasin Sayyidil Mursalin Muhammadan (Hermansyah, 2015).

Terjemahnya:

(Ya Allah, Tuhan Kami, saya bersaksi bahwa Engkau adalah Tuhan kami Saya bersaksi bahwa Nabi Muhammad Rasul Allah bagi jin dan manusia Kita ber-Islam dengan Iman, beserta makrifat dan tauhid

Kita tetap dalam kalimat hidup dan mati, ketika bangkit juga demikian

Berkat Rasulullah yang turun Kitab Nabi yang lengkap

Berkat Mukjizat, Taha, Yasin, Sayyidil Mursalin dan Muhammad)

\section{Idang Meulapeh}

Pada konteks makanan atau hidangan untuk maulod masyarakat Aceh jauh hari sudah mempersiapkannya secara bersahaja. Usman Budiman, Ketua Majelis Adat Aceh Kota Lhokseumawe menjelaskan, "Beberapa bulan sebelumnya masyarakat telah mempersiapkan hal-hal yang terkait dengan 
perayaan maulod. Misalnya, padi di sawah dipilih dengan kualitas terbaik dan spesial, pisang di kebun dipersiapkan yang buahnya banyak dan besar tidak punya cacat, mereka mengatakan, "Pisang ini jangan diganggu dan ditebang, kita akan simpan untuk maulid Nabi”. Demikian juga ayam jauh hari sebelumnya sudah ditangkap dan diikat di rumah Aceh tidak dilepaskan dan diberikan makan nasi dan beras saja, agar makanannya bersih dan tidak makanan kotor. Kesemuanya itu "mandum nyo ta persembahkan ke pang ulee alam" [dipersembahkan untuk penghulu alam Nabi Muhammad Saw] (wawancara, September 2015).

Termasuk di dalamnya menghubungi masyarakat Gampong dan mendata siapa saja yang membawa idang ke meunasah, baik hidangan biasa maupun idang meulapeh (hidangan yang bersusun dan berbagai macam). Disebutkan demikian, karena idang meulapeh berisi hidangan makanan yang lengkap yang ditempatkan dalam tempat khusus seperti talam yang ditutup dengan sange (sejenis penutup hidangan adat yang terbuat dari daun nipah yang dilapisi kain kasab yang berwarna merah, kuning dan hitam). Juga berisi makanan kue, isinya lengkap ikan, lauk pauk, makanan istimewa, bulukat (nasi ketan), bu kulah (nasi yang dibungkus daun pisang). Namun di beberapa kota dengan perkembangan zaman modern dan semangat urbanisme sebagain masyarakat lebih kepada nasi kotak.

Makanan yang disediakan di Meunasah dibawa oleh masyarakat sesuai dengan kemampuan di kawasan pedesaan. Mereka membawa idang yang terdiri dari nasi, ayam, daging dan berbagai makanan lainnya. Di wilayah kota seperti Banda Aceh, Lhokseumawe, Sabang biasanya masyarakat di samping membawa idang ke meunasah, mereka juga mengumpulkan uang untuk membeli lembu atau kambing yang dibuat kuah beulangon atau siee rebo (kuah daging sapi atau kerbau dimasak dengan berbagai rempah dalam kuali besar). Kuah beulangon disantap bersama bue kula sisanya dibagi kepada masyarakat. Ini biasanya dipraktikkan di Banda Aceh dan Aceh Besar, sedangkan di Pidie, Aceh Utara, terkenal dengan sie puteh (daging yang dimasak putih), mereka tidak makan di meunasah, tetap dibawa pulang ke rumah dan dimakan bersama keluarga.

Bagi mereka yang berekonomi tinggi, mereka akan mengorbankan sapi, kerbau, atau kambing. Hewan ternak tersebut menjadi bagian hidangan setelah digulai dengan berbagai macam jenis masakan. Begitu juga masyarakat yang tergolong tidak mampu juga merasa memiliki keharusan untuk ikut serta. Tidak jarang, sebagian dari mereka yang disebut terakhir ini, sengaja memelihara ayam dan itik yang diniatkan merayakan tradisi maulid di gampong nantinya. 
Perlu ditegaskan di sini bahwa kenduri maulid Nabi ini dilaksanakan di setiap peringkat sosial kehidupan masyarakat. Pada tingkatan terendah, maulid dilaksanakan oleh setiap gampong yang dikoordinir oleh keuchik (kepala desa). Hidangan kenduri disediakan oleh setiap keluarga yang menetap di kampung tersebut. Kenduri dilaksanakan di meunasah atau di bagian beranda masjid. Di sebagian daerah pelaksanaannya dilaksanakan di halaman masjid atau meunasah, karena menurut mereka pelaksanaan kenduri tidak boleh di dalam masjid demi menjaga kebersihan rumah ibadah itu.

Kenduri disajikan dalam hidang berlapis; antara tiga hingga tujuh lapis sesuai dengan kemampuan masing-masing keluarga. Meskipun demikian, masyarakat umumnya semua mampu untuk melaksanakan kenduri karena berpandangan bahwa yang dikendurikan itu merupakan hasil dari upaya mencari rezeki selama satu tahun, masyarakat sudah mencari selama sebelas bulan untuk digunakan dalam bulan ini (bulan Maulid). Oleh karena rezeki anggota masyarakat tidak sama, maka seandainya ada juga yang kurang mampu, maka mereka bergabung dengan dua atau tiga keluarga untuk menyiapkan satu hidangan maulid.

Hidangan yang biasanya terdiri atas tiga hingga tujuh lapis, di mana isinya tidak berbeda antara lapisan pertama dengan lapisan selanjutnya. Isi setiap lapis itu terdiri atas beberapa menu utama seperti pha manok (paha ayam kampong), dan boh itek jruek (telur asin). Kedua menu utama itu di sebagian daerah mempunyai makna filosofis bagi masyarakat sebagai bukti kesungguhan dalam menyediakan hidangan dalam kenduri pang ulee (Nabi Muhammad saw.). Kemudian jika maulid dilaksanakan di rumah maka biasanya akan disediakan peungat (Aceh Besar) atau kuah tuhe (Pidie), yaitu hidangan yang terdiri dari ketan, pisang raja, ketela atau ubi jalar, nangka dan kuah santan. Peungat merupakan hidangan penutup sesudah makan nasi dan lauk pauk.

\section{Dakwah Islamiah}

Pada malam hari sebagai kegiatan puncak Maulod, masyarakat mengadakan dakwah Islamiah yang berisikan tentang sirah Nabawiyah yang disampaikan oleh salah seorang ulama atau da'i terkenal, baik dalam kalangan masyarakat Aceh atau undangan dari luar Aceh. Tujuan ceramah tentang sirah nabawiyyah ini adalah untuk dijadikan sebagai ibrah oleh masyarakat Aceh dalam menata kehidupan dan meneladani sifat-sifat Rasulullah saw. dalam hidup keseharian. Biasanya masyarakat mengundang penceramah yang terkenal pada level 
kabupaten, provinsi, bahkan nasional, sesuai dengan kemampuan keuangan panitia.

Ceramah diadakan pada malam hari, semua masyarakat di gampong tersebut datang menghadiri dan demikian juga dari gampong tetangga. Ceramah di beberapa daerah bahkan ada yang dilakukan sampai tiga malam berturutturut dengan penceramah yang berbeda-beda. Meskipun tiga malam tetapi masyarakat masih ramai yang menghadirinya. Hidangan makanan hanya kue, kopi, teh dan air mineral sekedarnya saja. Itupun hanya untuk yang duduk di kursi dekat mimbar penceramah, sedangkan undangan yang berdiri di luar tidak disuguhi hidangan.

Sarana yang dipersiapkan untuk dakwah akbar berupa mimbar da'i juga tidak luput dari sentuhan seniman-seniman remaja setempat. Di samping itu disediakan pula berbagai jenis teratak untuk tempat para undangan yang akan mendengarkan ceramah atau dakwah maulod tersebut.

Kegiatan ceramah biasanya diadakan sesudah salat Isya sampai jam 10:3011:00 malam. Sebelum ceramah dimulai dengan pembacaan ayat al-Qur'an, yang dibacakan oleh qari atau qariah tingkat kabupaten atau provinsi bahkan nasional dan internasional. Kemudian diikuti sambutan pejabat setempat, keuchik (kepala desa), camat, bupati atau yang hadir pada saat itu. Materi ceramah berisi tentang sejarah dan peran Rasulullah saw, terkadang dikaitkan dengan isu-isu, masalah masyarakat yang sedang berkembang pada saat itu.

Memperingati maulod memiliki beberapa hikmah (Soelaiman, 2011: 164). Pertama, menumbuhkan dan mengembangkan sifat cinta dan patuh kepada Allah swt. dan Rasulullah saw. Kedua, menumbuhkan semangat juang dalam menjalani kehidupan dunia. Ketiga, mempertebal keimanan dalam upaya menghadapi setiap tantangan yang akan merusak kepribadian. Keempat, meningkatkan perasaan dan kebersamaan, sikap tolong-menolong dan ukhuwah Islamiah.

\section{Simpulan}

Sebagaimana tradisi yang lain, pola integrasi antara Islam dan budaya begitu tampak pada perayaan maulod dipraktikkan oleh masyarakat Aceh. Hal ini dapat dilihat dari uroe maulod, dzikee maulod, idang meulapeh dan dakwah Islamiah yang mengiringi prosesi tersebut. Bahkan tidak cukup hanya itu, perayaan maulod yang dilaksanakan dalam tiga bulan tersebut yaitu, bulan Rabiul Awal (mulod awai), Rabiul Akhir (mulod teungoh) dan pada bulan Jumadil Awal (mulod akhe).

el Harakah Jurnal Budaya Islam Vol.18 No.1 Tahun 2016 
Nilai-nilai yang muncul dari tradisi maulod dalam masyarakat yaitu, pertama, ketaatan; kepada Allah dalam arti bahwa mengikuti dan mencintai Rasulullah saw merupakan perintah Allah yang harus ditaati; kedua, kecintaan; merayakan maulod merupakan bagian dari rasa cinta kepada Nabi; ketiga, keikhlasan; pengorbanan baik harta, tenaga dan waktu adalah bentuk keikhlasan; keempat, kebersamaan; kehadiran masyarakat di meunasah secara bersama-sama merupakan bentuk kebersamaan yang memperkuat tatanan sosial; kelima, persaudaraan: undangan yang hadir dari masing-masing meunasah, gampong dan kemukiman mempererat ikatan sosial; keenam, persamaan; semangat equality dapat dilihat dari pada saat maulod tidak memandang status sosial dan ekonomi, orang tua dan anak-anak semua hadir.

\section{Daftar Pustaka}

Azra, Azyumardi. 1999. Konteks Berteologi di Indonesia: Pengalaman Islam, Jakarta: Paramadina.

2004. "Naskah dan Rekonstruksi Sejarah Sosial-Intelektual Nusantara" Makalah Simposium Internasional Pernaskahan VIII di Wisma Syahida UIN Syarif Hidayatullah, Jakarta 26-28 Juli.

Hadi, Abdul MW. 2006. Terjadi Kekosongan Kultural di Tubuh Umat Islam, Suara Muhammadiyah.

Hermansyah, 2015. Ini Dia Manuskrip Maulid Nabi, Serambi Indonesia, Edisi, Senin, 21 Desember.

Hoesein, Moehammad. 1970. Adat Atjeh, Banda Aceh: Dinas Kebudayaan Provinsi Daerah Istimewa Aceh.

Jati, Wasisto Raharjo. 2012. Tradisi, Sunnah dan Bid'ah: Analisa Barzanji dalam Perspektif Cultural Studies, Jurnal El Harakah, Vol. 14 No. 2, Tahun. http://Infopub.uin-malang/el harakah, diakses 26/12/2015.

Kaptein, Nico. 1994. Perayaan Maulid Nabi Muhammad SAW, Jakarta: IndonesianNedherlans Cooperation in Islamic Studies.

Koentjaraningrat. 1980. Beberapa Pokok Antropologi Sosial. Jakarta: Dian Rakyat.

Maimanah \& Norhidayat, 2012. Tradisi Baayun Mulud di Banjarmasin, Jurnal Al-Banjari, Vol. 11, No. 1, Januari. http://jurnal.iain-antasari.ac.id/index. php/albanjari, diakses, 26/12/2015. 
Melayu, Hasnul Arifin dkk. (Editor). 2012. Syiar Islam di Aceh, Banda Aceh: Dinas Syariat Islam.

Mudzhar, M. Atho. 1998. Pendekatan Studi Islam: Dalam Teori dan Praktik, Yogyakarta: Pustaka Pelajar.

Muhammad, Rusjdi Ali \& Sumardi, Dedy. 2011. Kearifan Tradisional Lokal: Penyerapan Syariat Islam dalam Hukum Adat Aceh, Banda Aceh: Dinas Syariat Islam.

Muhammad, Rusjdi Ali. 2005. Peranan Budaya dalam Merajut Kedamaian dan Silaturrahmi, dalam Darni Daud dkk. (ed), Budaya Aceh, Dinamika Sejarah dan Globalisasi, Banda Aceh: Unsyiah Press.

Nurdin, Abidin. 2013. Revitalisasi Kearifan Lokal Aceh: Peran Budaya dalam Menyelesaikan Konflik Masyarakat, Jurnal Analisis, Volume XIII, Nomor 1, Juni.

2015. Membangun Indonesia dari Aceh: Agama Pilar Pembangunan Sosial Budaya, Proceeding dalam Seminar Nasional "Membangun Indonesia Berbasis Nilai-Nilai Agama", APDISI dan Universitas Airlangga Surabaya, 19-20 November.

Pramono, 2010. Penulisan dan Pembacaan Cerita Maulid Nabi Penganut Tarekat Syattariyah di Padang, Jurnal Wacana Etnik, Volume 1, Nomor 1, April.

Purwadi, 2014. Harmony Masjid Agung Kraton Surakarta Hadiningrat, Ibda': Jurnal Kebudayaan Islam, Vol. 12, No. 1, Januari-Juni.http://ejournal. iainpurwokerto.ac.id./index.php/ibda, diakses 24/7/2015.

Schimmel, Annemarie. 1991. Dan Muhammad adalah Utusan Allah: Penghormatan terhadap Nabi Muhammad SAW dalam Islam. Terj. Rahmani Astuti dan Ilyas Yasan. Bandung: Mizan.

Sila, Muhammad Adlin. 2001. The Vestivity of Maulid Nabi in Cikoang, South Sulawesi: Between Remembering and Exaggerating the Spirit of the Prophet." In Studia Islamika, Vol. 8, No. 3. http://ejournal.uinjkt. ac.id.index.php.studi-islamika, diakses 25/7/2015.

Soelaiman, Darwis A. 2011. Kompilasi Adat Aceh, Banda Aceh: Pusat Studi Melayu Aceh.

el Harakah Jurnal Budaya Islam Vol.18 No.1 Tahun 2016 
